\title{
Reduction in health risk induced by semi-volatile organic compounds and metals in a drinking water treatment plant
}

\author{
F. Zhao $\cdot$ J. Yin $\cdot$ X.-X. Zhang $\cdot$ Y. Chen $\cdot$ \\ Y. Zhang $\cdot$ B. Wu $\cdot$ M. Li
}

Received: 25 January 2013/Revised: 5 September 2013/Accepted: 3 November 2013/Published online: 27 November 2013

(C) Islamic Azad University (IAU) 2013

\begin{abstract}
This study investigated health risk reduction in a drinking water treatment plant of Nanjing City (China) based on chemical detection of 22 semi-volatile organic compounds (SVOCs) and 24 metallic elements in source water and drinking water during 2009-2011. Chemical analysis showed that 15 SVOCs and 9 metals were present in the water. Health risk assessment revealed that hazard quotient of each pollutant and hazard index (HI) of all the detectable pollutants were below 1.00, indicating that the chemicals posed negligible non-carcinogenic risk to local residents. Benzo(a)pyrene may induce carcinogenic risk since its risk index via both oral and dermal exposure exceeded the safety level (1.00E-6), but other SVOCs induced no carcinogenic risk. Total HI of the SVOCs was $1.08 \mathrm{E}-3$ for the source water and $1.56 \mathrm{E}-3$ for the drinking water, suggesting that the used conventional treatment processes (coagulation/sedimentation, sand filtration and chlorine disinfection) cannot effectively reduce the non-carcinogenic risk. The source water had higher carcinogenic risk than the drinking water, but risk index of the drinking water still exceeded $1.00 \mathrm{E}-6$. This study might serve as a basis for health risk assessment of drinking water and also as a benchmark for the authorities to reduce health risk arising from trace-level hazardous pollutants.
\end{abstract}

F. Zhao $\cdot$ J. Yin $\cdot$ X.-X. Zhang $(\square)$

Y. Chen $\cdot$ Y. Zhang $\cdot$ B. Wu $\cdot$ M. Li

State Key Laboratory of Pollution Control and Resource Reuse,

School of the Environment, Nanjing University,

Nanjing 210023, China

e-mail: zhangxx@nju.edu.cn
Keywords Carcinogenic risk - Metallic elements · Non-carcinogenic risk - Semi-volatile organic compounds · Source and drinking water

\section{Introduction}

Recently, contamination of drinking water has received growing concern in developing countries along with economic development. In China, the Yangtze River provides the source of drinking water supplied for over 0.4 billion people living along the river. The Yangtze River basin generates $30-40 \%$ of China's GDP, but annually over 30 billion tons industrial and domestic wastewater is discharged in the river; especially, at the middle and lower reaches, the river is suffering from enormous environmental deterioration due to rapid industrialization of this region. Previous studies have demonstrated that the Yangtze River has been contaminated by a variety of organic and inorganic pollutants, such as polycyclic aromatic hydrocarbons (PAHs) (Wu et al. 2011a, b; Xu et al. 2001), polychlorinated biphenyls (Sun et al. 2002), environmental endocrine disruptors (Wu et al. 2009a, b) and heavy metals (Muller et al. 2008; Wu et al. 2009a). Presence of the contaminants in the river water is possibly threatening the health of local residents.

Environmental health risk assessment models recommended by Environmental Protection Agency of the United Nations (USEPA) are generally accepted for health risk assessment and have been widely used to evaluate the potential health risk induced by the contaminants in the source water (Wu et al. 2009a) and drinking water (Wu et al. 2010). Our previous study has revealed that lab-scale biofilters are effective in pollutant removal and risk reduction in drinking water treatment, but non-carcinogenic and carcinogenic risk still cannot reached safety 
levels for finished water. It is known that the processes of coagulation/sedimentation, sand filtration and chlorine disinfection are usually used in drinking water treatment plants in China (Xie et al. 2010). However, few studies have been conducted to evaluate effects of the conventional treatment processes on the reduction in the induced health risk.

This study firstly determined the concentrations of 22 semi-volatile organic compounds (SVOCs) and 24 metallic elements in the source water and drinking water sampled from a tap water plant of Nanjing City located in the low reach of the Yangtze River during 2009-2011. Non-carcinogenic and carcinogenic health risk of each contaminant were further assessed to investigate the effect of the water treatment on health risk reduction.

\section{Materials and methods}

Sample collection

Water was sampled from the largest tap water plant (Beihekou Tap Water Plant) in Nanjing City (located at $32.05^{\circ} \mathrm{N}$ and $118.72^{\circ} \mathrm{E}$ ), which provides approximately $65,000 \mathrm{~m}^{3}$ drinking water per day for $50 \%$ of the local residents in the city. Drinking water undergoes a series of treatment processes, including coagulation/sedimentation, sand filtration and chlorine disinfection before entering into pipeline distribution system. Source water was sampled from the influent of coagulation tank, and drinking water was sampled from effluent of disinfection tank.

To avoid seasonal bias, water samples were collected four times separately in March and June 2009, June 2010 and September 2011 to investigate the effect of the water treatment on health risk reduction. The information about baseline water quality of SW and DW has been described in previous studies (Chen et al. 2012; Shi et al. 2013). Water samples (10 L each) were collected in brown glass bottles, which were initially immersed in chromosulfuric acid for $24 \mathrm{~h}$, then washed with deionized water eight times and finally rinsed with raw water three times. One or two drops of concentrated hydrochloric acid and $1 \mathrm{~g}$ ascorbic acid were added into each sample $(10 \mathrm{~L})$ to reach $\mathrm{pH}<2.0$ and inhibit biodegradation of the analytes. The samples were then transported to laboratory within $2 \mathrm{~h}$ before they went through $0.45-\mu \mathrm{m}$ micropore membrane filters. The filtered water samples were stored in three brown glass bottles $\left(1 \mathrm{~L}\right.$ each) at $4{ }^{\circ} \mathrm{C}$ until chemical analysis.

Analytical methods for SVOCs

In this study, $5 \mathrm{~mL}$ of methanol was added into $1 \mathrm{~L}$ of each water sample before extraction using liquid-solid extraction method (Zhang et al. 2011; Grimmett and Munch 2013). Firstly, water went through the C18 cartridges after they were cleaned with $5 \mathrm{~mL}$ ethyl acetate and $5 \mathrm{~mL}$ methylene chloride at a maximum flow rate of $10 \mathrm{~mL} / \mathrm{min}$. The cartridges concentrated with organic compounds were then connected with the drying tube and eluted with $5 \mathrm{~mL}$ ethyl acetate, followed by $5 \mathrm{~mL}$ methylene chloride and $3 \mathrm{~mL}$ mixture of ethyl acetate and methylene chloride $(1: 1$ of $\mathrm{v} / \mathrm{v})$. The extracts were concentrated with nitrogen evaporation apparatus to reach $1 \mathrm{~mL}$ before analysis using a DSQ II Single Quadrupole GC/MS (ThermoQuest, San Jose, CA, USA) with selected ion monitoring (SIM) mode. Quantification of individual compounds was based on comparisons of peak areas with those of the standards.

The 22 SVOCs tested in this study included: 10 PAHs [acenaphthylene (ACE), anthracene (ANT), benzo(a)anthracene $(\mathrm{BaA})$, benzo(a)pyrene $(\mathrm{BaP})$, benzo(b)fluoranthene $(\mathrm{BbF})$, benzo $(\mathrm{k})$ fluoranthene $(\mathrm{BkF})$, chrysene $(\mathrm{CHR})$, fluorine (FLU), phenanthrene (PHE) and pyrene (PYR)], 6 phthalate ethers (PAEs) [bis-2-ethylhexyl adipate (DEHA), bis(2-ethylhexyl) phthalate (DEHP), di- $n$-butyl phthalate (DBP), diethyl phthalate (DEP), dimethyl phthalate (DMP) and benzyl butyl phthalate (BBP)], 3 organochlorine compounds (OCCs) [hexachlorocyclopentadiene (HCCP), hexachlorobenzene (HCB) and pentachlorophenol (PCP)] and other organic pollutants [isophorone (ISO), 2,4-ditrotoluene (2,4-DNT) and 2,6-dinitrotoluene (2,6-DNT)].

\section{Analytical methods for metallic elements}

For metal analysis, water samples (10 mL each) were collected into a metal free polyethylene bottle and digested $(\mathrm{pH}<2)$ with concentrated nitric acid before they were filtered through a cellulose acetate membrane filter $(0.45$ $\mu \mathrm{m}$ pore size). Dissolved 24 metallic elements, including $\mathrm{Al}, \mathrm{B}, \mathrm{Ba}, \mathrm{Ca}, \mathrm{Cd}, \mathrm{Co}, \mathrm{Cr}, \mathrm{Cu}, \mathrm{Fe}, \mathrm{K}, \mathrm{Mg}, \mathrm{Mn}, \mathrm{Mo}, \mathrm{Na}, \mathrm{Ni}$, $\mathrm{Pb}, \mathrm{Sb}, \mathrm{Se}, \mathrm{Si}, \mathrm{Sn}, \mathrm{Sr}, \mathrm{Ti}, \mathrm{V}$ and $\mathrm{Zn}$, were analyzed using inductively coupled plasma-atomic emission spectroscopy (ICP-AES; Jarrell-Ash 1100, USA). The sample pretreatment and instrumental analysis was conducted following the methods recommended by the Babu et al. (2007) and Liu et al. (2011, 2012). Significant difference for the concentrations of the detectable metals between source water and drinking water was analyzed by $t$ test with heteroscedasticity assumptions of the two samples.

Analytical quality controls

All reagents used in this study were of chromatographic purity grade. Reagent blanks, standard reference materials and sample replicates were applied during the chemical analysis of the SVOCs and metallic elements to assess 
Table 1 Concentrations of semi-volatile organic compounds (SVOCs) in the source water (SW) and drinking water (DW) (unit: ng $\mathrm{L}^{-1}$ )

\begin{tabular}{|c|c|c|c|c|c|c|c|c|c|c|c|c|c|}
\hline \multirow[t]{2}{*}{ SVOCs } & \multirow{2}{*}{$\begin{array}{l}\text { Detection } \\
\text { limits }\end{array}$} & \multicolumn{2}{|c|}{ Mar-09 } & \multicolumn{2}{|l|}{ Jun-09 } & \multicolumn{2}{|l|}{ Jun-10 } & \multicolumn{2}{|c|}{ Sep-11 } & \multicolumn{2}{|l|}{ Mean } & \multicolumn{2}{|l|}{ Range } \\
\hline & & SW & DW & SW & DW & SW & DW & SW & DW & SW & DW & SW & DW \\
\hline \multicolumn{14}{|l|}{ PAHs } \\
\hline ACE & 0.5 & N.D. & N.D. & N.D. & N.D. & N.D. & N.D. & 6.59 & N.D. & 1.65 & N.D. & N.D.-6.59 & N.D. \\
\hline ANT & 0.4 & 6.59 & 3.95 & 6.99 & 3.42 & 44.31 & 63.13 & 23.69 & 22.94 & 20.40 & 23.36 & $6.59-44.31$ & $3.42-63.13$ \\
\hline $\mathrm{BaP}$ & 0.5 & 48.28 & 13.97 & 2.64 & 3.99 & 4.59 & N.D. & N.D. & N.D. & 13.88 & 4.49 & N.D. -48.28 & N.D. -13.97 \\
\hline $\mathrm{BbF}$ & 0.5 & 41.10 & 19.87 & 1.62 & 2.12 & 5.72 & N.D. & N.D. & N.D. & 12.11 & 5.50 & N.D. -41.10 & N.D. -19.87 \\
\hline $\mathrm{BkF}$ & 0.5 & 14.11 & N.D. & 1.39 & 2.04 & 3.55 & N.D. & N.D. & N.D. & 4.76 & 0.51 & N.D. -14.11 & N.D.-2.04 \\
\hline CHR & 0.5 & 28.02 & 20.55 & 2.69 & 2.59 & 4.02 & 2.11 & N.D. & N.D. & 8.68 & 6.31 & N.D. -28.02 & N.D. -20.55 \\
\hline \multicolumn{14}{|l|}{ PAEs } \\
\hline BBP & 1.0 & N.D. & N.D. & N.D. & N.D. & 73.4 & 31.95 & 92.11 & 86.66 & 41.38 & 29.65 & N.D. -92.11 & N.D. -86.66 \\
\hline DEP & 0.5 & 5.63 & 4.07 & 6.05 & 5.41 & N.D. & N.D. & 37.54 & 38.99 & 12.31 & 12.12 & N.D. -37.54 & N.D. -38.99 \\
\hline DMP & 0.4 & 22.18 & 25.25 & 28.69 & 24.43 & 123.56 & 106.94 & 49.41 & 49.52 & 55.96 & 51.54 & $22.18-123.56$ & $24.43-106.94$ \\
\hline \multicolumn{14}{|l|}{ OCCs } \\
\hline PCP & 0.5 & 16.78 & 10.48 & 11.36 & 13.93 & N.D. & N.D. & N.D. & N.D. & 7.03 & 6.10 & N.D. -16.78 & N.D. -13.93 \\
\hline $\mathrm{HCB}$ & 0.5 & 6.93 & 1.73 & 2.05 & 1.39 & N.D. & N.D. & N.D. & 53.74 & 2.25 & 14.22 & N.D.-6.93 & N.D. -53.74 \\
\hline $\mathrm{HCCP}$ & 1.0 & N.D. & N.D. & N.D. & 20.23 & N.D. & 8.77 & N.D. & N.D. & N.D. & 7.25 & N.D. & N.D. -20.23 \\
\hline \multicolumn{14}{|l|}{ Others } \\
\hline $\begin{array}{l}2,4- \\
\text { DNT }\end{array}$ & 1.0 & 5.63 & 4.07 & 6.05 & 5.41 & 60.3 & 36.37 & N.D. & N.D. & 17.99 & 11.46 & N.D. -60.3 & N.D. -36.37 \\
\hline $\begin{array}{l}2,6- \\
\text { DNT }\end{array}$ & 0.5 & N.D. & N.D. & 0.38 & N.D. & N.D. & N.D. & N.D. & N.D. & 0.09 & N.D. & N.D. -0.38 & N.D. \\
\hline ISO & 1.0 & N.D. & N.D. & N.D. & 1.46 & 10.89 & 13.97 & 51.25 & 16.33 & 15.54 & 7.94 & N.D. -51.25 & N.D. -16.33 \\
\hline
\end{tabular}

N.D. not detectable, PAHs polycyclic aromatic hydrocarbons, PAEs phthalate ethers, OCCs organ chlorine compounds, Others other organic pollutants

contamination and precision. For recovery studies of the SVOCs and metallic elements, a series of standard solutions were made up from a stock solution and the recovery rates were above $82.8 \%$ for the SVOCs and above $90.5 \%$ for the trace elements, suggesting the efficiency of the used methods. The detection limits of contaminants were determined with a signal-to-noise ratio $(\mathrm{S} / \mathrm{N})$ of 3 (Tables 1 and 2). Chemical analysis of the SVOCs (Zhang et al. 2011; Chen et al. 2012; Grimmett and Munch 2013) and metallic elements (Babu et al. 2007; Wu et al. 2009a) was conducted in triplicate for each sample, and the average concentration of each chemical in the different samples collected during 2009-2011 was used for health risk assessment.

\section{Health risk assessment}

The induced health risk was assessed for the detectable SVOCs and metallic elements in the source water and finished water. Health risk assessment was carried out on a basis of reliable exposure pathways of contaminants (USEPA (US Environmental Protection Agency) 2012a, c). Exposure to the chemicals was considered mainly via the following pathways: direct ingestion of water consumption and dermal absorption of contaminants in water adhered to exposed skin. Carcinogenic and non-carcinogenic risks were assessed based on the two exposure pathways in this study. The assessment included exposure dose determination (ingestion and dermal absorption pathway), hazard quotient calculation, non-carcinogenic hazard index (HI) and carcinogenic risk index (RI) calculation, and uncertainty analysis.

The ingestion and dermal exposure doses were calculated by Eqs. 1 and 2, respectively, which were adapted from USEPA (US Environmental Protection Agency) (2012c):

$\mathrm{Di}=\frac{\mathrm{Cw} \times \mathrm{IR} \times \mathrm{EF} \times \mathrm{ED}}{\mathrm{BW} \times \mathrm{AT}}$

$\mathrm{Dd}=\frac{\mathrm{Cw} \times \mathrm{SA} \times \mathrm{Kp} \times \mathrm{ET} \times \mathrm{EF} \times \mathrm{ED} \times \mathrm{CF}}{\mathrm{BW} \times \mathrm{AT}}$

where Di $\left(\mu \mathrm{g} \mathrm{kg}^{-1} \mathrm{day}^{-1}\right)$, exposure dose through ingestion of water; $\mathrm{Dd}\left(\mu \mathrm{g} \mathrm{kg}^{-1} \mathrm{day}^{-1}\right)$, exposure dose through dermal absorption; $\mathrm{Cw}\left(\mu \mathrm{g} \mathrm{L}^{-1}\right)$, average concentration of organic pollutant and metallic element in water samples collected during 2009-2011; Kp $\left(\mathrm{cm} \mathrm{h}^{-1}\right)$, 
Table 2 Concentrations of metallic elements in the source water (SW) and drinking water (DW) (unit: $\mu \mathrm{g} \mathrm{L}^{-1}$ )

\begin{tabular}{|c|c|c|c|c|c|c|c|c|c|c|c|c|c|}
\hline \multirow[t]{2}{*}{ Elements } & \multirow[t]{2}{*}{ Detection limits } & \multicolumn{2}{|c|}{ Mar-09 } & \multicolumn{2}{|c|}{ Jun-09 } & \multicolumn{2}{|c|}{ Jun-10 } & \multicolumn{2}{|c|}{ Sep-11 } & \multicolumn{2}{|l|}{ Mean } & \multicolumn{2}{|l|}{ Range } \\
\hline & & SW & DW & SW & DW & SW & DW & SW & DW & SW & DW & SW & DW \\
\hline $\mathrm{Al}$ & 9 & 918 & 850 & 23 & 863 & 619 & 35 & 11 & 36 & 393 & 446 & $11-918$ & $35-863$ \\
\hline $\mathrm{Ba}$ & 4 & 46 & 50 & 43 & 52 & 45 & 50 & 38 & 59 & 43 & 53 & $38-46$ & $50-59$ \\
\hline $\mathrm{Ca}\left(\times 10^{3}\right)$ & 5 & 29.44 & 28.41 & 30.83 & 31.44 & 32.16 & 32.29 & 44.27 & 39.63 & 34.17 & 32.94 & $29.44-44.27$ & $28.41-39.63$ \\
\hline $\mathrm{Fe}$ & 2 & 462 & 424 & 14 & 417 & 257 & 12 & N.D. & N.D. & 183 & 213 & N.D. -462 & N.D. -424 \\
\hline $\mathrm{K}\left(\times 10^{3}\right)$ & 21 & 2.46 & 2.60 & 2.27 & 2.59 & 2.79 & 2.63 & 7.54 & 2.54 & 3.77 & 2.59 & $2.27-7.54$ & $2.54-2.63$ \\
\hline $\operatorname{Mg}\left(\times 10^{3}\right)$ & 12 & 6.95 & 6.96 & 7.15 & 6.93 & 6.43 & 6.15 & 19.13 & 8.72 & 9.92 & 7.19 & $6.43-19.13$ & $6.15-8.72$ \\
\hline $\mathrm{Na}\left(\times 10^{3}\right)$ & 5 & 8.53 & 9.19 & 8.67 & 8.82 & 8.77 & 8.17 & 77.37 & 16.00 & 25.83 & 10.55 & $8.53-77.37$ & $8.17-16.00$ \\
\hline $\mathrm{Si}\left(\times 10^{3}\right)$ & 10 & 4.75 & 4.51 & 3.28 & 4.75 & 3.62 & 2.87 & 5.48 & 3.95 & 4.28 & 4.02 & $3.28-5.48$ & $2.87-4.75$ \\
\hline $\mathrm{Sr}$ & 6 & 186 & 201 & 200 & 207 & 180 & 180 & 237 & 240 & 201 & 207 & $180-237$ & $180-240$ \\
\hline
\end{tabular}

N.D. not detectable

dermal permeability coefficient; IR $\left(1.43 \mathrm{~L} \mathrm{day}^{-1}\right)$, ingestion rate; ET $\left(20 \mathrm{~min} \mathrm{day}^{-1}\right)$, exposure time (USEPA (US Environmental Protection Agency) 2012d); EF (365 days year ${ }^{-1}$ ), exposure frequency; ED (year), exposure duration (73.91 years), in this study, equal to the life expectancy at Jiangsu Province, China (MHPRC (Ministry of Health of the People's Republic of China) 2012); CF, unit conversion factor; BW (57.38 kg), average body weight, in this study, equal to the average weight of urban males and females in the 18-80 age group (MHPRC (Ministry of Health of the People's Republic of China) 2012); AT (day), averaging time, for non-carcinogens and carcinogens; SA $\left(\mathrm{cm}^{2}\right)$, exposed skin area calculated by Eq. 3 (Zhang et al. 2011):

$\mathrm{SA}=0.007182 \times H^{0.7252} \times \mathrm{BW}^{0.425} \times 10^{4}$

where $H\left(152.09 \mathrm{~cm}^{2}\right)$, average body weight of urban males and females in the 18-80 age group according to MHPRC (Ministry of Health of the People's Republic of China) (2012); $10^{4}$, area unit conversion factor.

Non-carcinogenic risk is expressed in terms of a hazard quotient (HQ) for a single substance, or HI for multiple substances and/or exposure pathways. HQ was calculated by Eq. 4 to estimate non-carcinogenic risk of each contaminant:

$\mathrm{HQ}=D / \mathrm{RfD}$

where $D\left(\mu \mathrm{g} \mathrm{kg}^{-1} \mathrm{day}^{-1}\right)$, the exposure dose obtained from the Eqs. 1 and 2; $\operatorname{RfD}\left(\mu \mathrm{gg}^{-1}\right.$ day $\left.^{-1}\right)$, the reference dose of the contaminant. The ingestion reference dose $\left(\mathrm{RfD}_{\mathrm{i}}\right)$ values were obtained from the USEPA (US Environmental Protection Agency) (2012b). The $\mathrm{RfD}_{\mathrm{i}}$ was multiplied by a gastrointestinal absorption factor $\left(\mathrm{ABS}_{\mathrm{g}}\right)$ to yield the corresponding dermal absorption reference dose $\left(\mathrm{RfD}_{\mathrm{d}}\right)$.
Hazard index (HI), the total HQ for multiple substances, was summed by Eq. 5 to assess the overall non-carcinogenic risk posed by all chemicals:

$\mathrm{HI}=\mathrm{HQ}_{1}+\mathrm{HQ}_{2}+\cdots+\mathrm{HQ}_{\mathrm{n}}$

Lifetime carcinogenic risk (LCR) is defined as the incremental probability that an individual will develop cancer during one's lifetime due to chemical exposure under specific scenarios (Chen and Liao 2006). LCR induced by ingestion and dermal exposure was calculated using Eq. 6:

$\mathrm{LCR}=D \times \mathrm{SF}$

where LCR, the probability of developing cancer over a lifetime as a result of exposure to a contaminant; $D\left(\mu \mathrm{g} \mathrm{kg}^{-1} \mathrm{day}^{-1}\right)$, the exposure dose obtained from the Eqs. 1 and 2; SF $\left(\mu \mathrm{g} \mathrm{kg}^{-1} \mathrm{day}^{-1}\right)^{-1}$, the carcinogenic slope factor of the contaminant.

The ingestion slope factor $\left(\mathrm{SF}_{\mathrm{i}}\right)$ values were obtained from the USEPA (US Environmental Protection Agency) (2012b). The $\mathrm{SF}_{\mathrm{i}}$ was divided by a gastrointestinal absorption factor $\left(\mathrm{ABS}_{\mathrm{g}}\right)$ to yield the corresponding dermal absorption slope factor $\left(\mathrm{SF}_{\mathrm{d}}\right)$. RI of all chemicals was calculated by summing the LCR of individual chemical using Eq. 7 to assess the overall potential for carcinogenic risk effects:

$\mathrm{RI}=\mathrm{LCR}_{1}+\mathrm{LCR}_{2}+\cdots+\mathrm{LCR}_{\mathrm{n}}$

To avoid the uncertainty in the estimation of exposure risk, the toxicity values ( $\mathrm{RfD}, \mathrm{Kp}$ and $\mathrm{SF}$ ) of each contaminant recommended by USEPA (US Environmental Protection Agency) (2012b) were directly applied, and the variables of $\mathrm{Cw}, \mathrm{IR}, \mathrm{ED}, \mathrm{SA}, \mathrm{BW}$ and ET were evaluated based on the local statistical data and USEPA reference data. Table 3 lists the values of $\mathrm{Kp}$, $\mathrm{RfD}_{\mathrm{i}}, \mathrm{SF}_{\mathrm{i}}$ and $\mathrm{ABS}_{\mathrm{g}}$ used for health risk assessment. 
Table 3 Values of parameters in calculation models used for health risk assessment

\begin{tabular}{|c|c|c|c|c|c|}
\hline Types & Pollutants & $\begin{array}{l}\mathrm{Kp} \\
\left(\mathrm{cm} \mathrm{h}^{-1}\right)\end{array}$ & $\begin{array}{l}\operatorname{RfD}_{\mathrm{i}} \\
\left(\mu \mathrm{gg}^{-1} \mathrm{day}^{-1}\right)\end{array}$ & $\begin{array}{l}\mathrm{SF}_{\mathrm{i}} \\
\left(\mu \mathrm{g} \mathrm{kg}^{-1} \mathrm{day}^{-1}\right)\end{array}$ & $\mathrm{ABS}_{\mathrm{g}}$ \\
\hline \multirow[t]{6}{*}{ PAHs } & Acenaphthylene & $1.41 \mathrm{E}-01$ & $1.50 \mathrm{E}+04$ & N.D. & $6.00 \mathrm{E}-01$ \\
\hline & Anthracene & $2.25 \mathrm{E}-01$ & $3.00 \mathrm{E}+02$ & N.D. & $7.60 \mathrm{E}-01$ \\
\hline & Benzo(a)pyrene & $1.20 \mathrm{E}+00$ & N.D. & $7.30 \mathrm{E}-03$ & $7.00 \mathrm{E}-01$ \\
\hline & Benzo(b)fluoranthene & N.D. & N.D. & $7.30 \mathrm{E}-04$ & $7.00 \mathrm{E}-01$ \\
\hline & Benzo(k)fluoranthene & N.D. & N.D. & $7.30 \mathrm{E}-05$ & $7.00 \mathrm{E}-01$ \\
\hline & Chrysene-d 12 & $8.10 \mathrm{E}-01$ & N.D. & $7.30 \mathrm{E}-06$ & $8.00 \mathrm{E}-01$ \\
\hline \multirow[t]{3}{*}{ PAEs } & Benzyl butyl phthalate & N.D. & $2.00 \mathrm{E}+02$ & $1.90 \mathrm{E}-06$ & $5.00 \mathrm{E}-01$ \\
\hline & Diethyl phthalate & $2.80 \mathrm{E}-05$ & $8.00 \mathrm{E}+02$ & N.D. & $5.00 \mathrm{E}-01$ \\
\hline & Dimethyl phthalate & $1.60 \mathrm{E}-03$ & $8.00 \mathrm{E}+02$ & N.D. & $5.00 \mathrm{E}-01$ \\
\hline \multirow[t]{3}{*}{ OCCs } & Hexachlorobenzene & $2.10 \mathrm{E}-01$ & $8.00 \mathrm{E}-01$ & $1.30 \mathrm{E}-04$ & $5.00 \mathrm{E}-01$ \\
\hline & Hexachlorocyclopentadiene & $1.56 \mathrm{E}-01$ & $6.00 \mathrm{E}+00$ & N.D. & $5.00 \mathrm{E}-01$ \\
\hline & Pentachlorophenol & $6.50 \mathrm{E}-01$ & $5.00 \mathrm{E}+00$ & $4.00 \mathrm{E}-04$ & $5.00 \mathrm{E}-01$ \\
\hline \multirow[t]{3}{*}{ Others } & 2,4-dinitrotoluene & $3.76 \mathrm{E}-03$ & $2.00 \mathrm{E}+00$ & $3.10 \mathrm{E}-04$ & $8.50 \mathrm{E}-01$ \\
\hline & 2,6-dinitrotoluene & $4.57 \mathrm{E}-03$ & $1.00 \mathrm{E}+00$ & $1.05 \mathrm{E}-03$ & $8.50 \mathrm{E}-01$ \\
\hline & Isophorone & $4.40 \mathrm{E}-03$ & $2.00 \mathrm{E}+02$ & $9.50 \mathrm{E}-07$ & $5.00 \mathrm{E}-01$ \\
\hline \multirow[t]{4}{*}{ Metals } & $\mathrm{Al}$ & $2.14 \mathrm{E}-03$ & $1.00 \mathrm{E}+03$ & N.D. & $1.00 \mathrm{E}-01$ \\
\hline & $\mathrm{Ba}$ & $4.03 \mathrm{E}-04$ & $2.00 \mathrm{E}+02$ & N.D. & $7.00 \mathrm{E}-02$ \\
\hline & $\mathrm{Fe}$ & N.D. & $7.00 \mathrm{E}+02$ & N.D. & $2.00 \mathrm{E}-01$ \\
\hline & $\mathrm{Sr}$ & N.D. & $6.00 \mathrm{E}+02$ & N.D. & $2.00 \mathrm{E}-01$ \\
\hline
\end{tabular}

N.D. not detectable, PAHs polycyclic aromatic hydrocarbons, PAEs phthalate ethers, OCCs organ chlorine compounds, Others other organic pollutants, $K p$ dermal permeability coefficient, $R f D_{i}$ ingestion reference dose, $S F_{i}$ ingestion slope factor, $A B S_{g}$ gastrointestinal absorption factor

\section{Results and discussion}

Concentration of SVOCs and metallic elements

Table 1 shows the concentration of the individual SVOCs present in the source water and drinking water. Among the 22 SVOCs tested in this study, 15 chemicals were detectable, including 6 PAHs (ACE, ANT, BaP, BbF, BkF and CHR), 3 PAEs (DEP, DMP and BBP), 3 OCCs (HCB, HCCP and PCP) and other organic pollutants (2, 4-DNT, 2, 6-DNT and ISO). The total concentration of SVOCs was $214.01 \mathrm{ng} \mathrm{L}^{-1}$ in the source water and $180.40 \mathrm{ng} \mathrm{L}^{-1}$ in the drinking water. Concentrations of most SVOCs showed evident variation at different sampling time points. The average concentration of PAHs, PAEs, OCCs and others was $60.47,109.64,9.28$ and $33.62 \mathrm{ng} \mathrm{L}^{-1}$ in the source water and 40.17, 93.31, 27.52 and $19.40 \mathrm{ng} \mathrm{L}^{-1}$ in the drinking water, respectively. The total concentration of the detectable SVOCs (especially for PAEs) in source water was lower than the results of $\mathrm{Wu}$ et al. (2009a) who quantified the organic contaminants in the Yangtze River in 2007. The Yangtze River source water had the lower level of PAHs than the Nantong reach of the Yangtze River (Han et al. 2013), the Minjiang River (72.4 $\mu \mathrm{g} \mathrm{L}^{-1}$ ) (Zhang et al. 2004), the Qiantang River (288.2 ng L ${ }^{-1}$ ) (Zhu et al. 2008) and the Yellow River (453.9 $\mathrm{ng} \mathrm{L}^{-1}$ ) ( $\mathrm{Li}$ et al. 2006). However, the concentrations of PAEs in the drinking water were comparable to those of other regions in Jiangsu Province (China) (Li et al. 2012). The high level of PAEs may result from the wide use of plastics in these areas and high aqueous solubility of PAEs ( $\mathrm{Li}$ et al. 2006). Comparatively, the source water had higher concentration of the SVOCs than the drinking water. In this drinking water treatment plant, more than $15.70 \%$ of the detectable chemicals were removed, which is similar to the removal efficiency of the plants in the cities of Pexian, Dafen, Wojin and Binhu (China) applying the same treatment processes ( $\mathrm{Li}$ et al. 2012). However, the concentration of OCCs in the source water was lower than in the drinking water. HCB had higher concentration in the drinking water than in the source water, which is close to concentration of HCB in drinking water of Canada (Oliver and Nlcol 1982). HCCP was not detectable in the source water, but occurred in the drinking water. This may result from the chlorination effects in disinfection process that produces free and combined chlorine species, particularly $\mathrm{HClO}$ and $\mathrm{NH}_{2} \mathrm{Cl} /$ $\mathrm{NHCl}_{2}$, since previous studies have indicated that various chlorides tend to have higher levels in drinking water after chlorine disinfection (Qin et al. 2010; Florentina et al. 2011; Zhao et al. 2012). Recently, growing concerns focus 
upon the removal of SVOCs in drinking water. Activated carbons (Dąbrowski et al. 2005) and porous polymeric resin (Król et al. 2011) are considered reliable methods for absorption of the organic compounds, while the operational cost is too high for large-scale application of the processes in drinking water plants. Chen et al. (2012) showed that biofilters combined backwashing with air and water at an appropriate intensity are effective on removal of the pollutants.

Among the 24 metallic elements tested, 9 metals were found to be present in the source water or drinking water (Table 2). $\mathrm{Ca}, \mathrm{Na}, \mathrm{Mg}, \mathrm{Si}$ and $\mathrm{K}$ contributed $99 \%$ of the total amount of the detectable metals in the source water and drinking water. Although $\mathrm{Ca}$ and $\mathrm{Na}$ had evidently higher levels than other metals in the water samples, the concentrations of the two metals did not exceed the prescribed levels of WHO (World Health Organization) (2012). The concentrations of the metals in the Yangtze River source water were lower than or close to previous studies (Zhang 1995; Muller et al. 2008). However, levels of $\mathrm{Al}$ determined in this study were approximately ten times higher than those in the River Thames (Neal et al. 2006a, b). The drinking water treatment processes seemed not effective in removing most of the metals, since the levels of the metals showed no significant difference between the source water and drinking water $(p>0.05)$. This is supported by previous studies indicating that the conventional processes of coagulation and sand filtration cannot effectively remove the soluble metals in drinking water (Dubey et al. 2009; Noubactep 2010).

Non-carcinogenic risk of SVOCs and metallic elements

To further assess the health risk induced by the SVOCs and metals in the source water and drinking water, non-carcinogenic risk was assessed using the methods recommended by USEPA. For most chemicals, the potential for non-carcinogenic effects is evaluated by calculating HQ (USEPA (US Environmental Protection Agency) 2012c). If the HQ exceeds 1.00 , there is some possibility that noncarcinogenic effects may occur. Otherwise, it is believed that there is no appreciable risk that non-carcinogenic health effects will occur.

In this study, the HQ value of each detectable pollutant in the source water and drinking water was $<1.00$ (Fig. 1), indicating that each contaminant individually posed no potential non-carcinogenic risk to local residents via ingestion and dermal exposure. In terms of the integrated health risk, the HI values of the SVOCs in both the source water and drinking water were $<1.00$ via ingestion or dermal exposure (Fig. 1a). It should be noted that OCCs contributed most to the total non-carcinogenic risk in the source water and drinking water. In the case of ingestion exposure, OCCs accounted for $39.14 \%$ of $\mathrm{HI}$ in source water and $77.85 \%$ of $\mathrm{HI}$ in drinking water; especially, the contribution proportion of OCCs was approximately $99 \%$ when dermal exposure to the source water or drinking water. Among various OCCs, HCB and PCP contributed most to the total non-carcinogenic risk of the drinking water, although the concentrations of the two chemicals were lower than most of the other organic compounds. As a typical carcinogen, HCB can cause systemic impairment (thyroid, liver, bone and skin), as well as damages to the kidneys, blood cells, and the immune, endocrine, developmental and nervous systems (Reed et al. 2007). In vitro and in vivo evidences have revealed that PCP can induce reproductive (Orton et al. 2009), immune (Corsini et al. 2008) and nervous (McLean et al. 2009) toxicities.

Among the 9 detectable metals in the water samples, 4 metals were selected for the HQ calculation (Fig. 1b) since the RfD values are available for those metals (USEPA (US Environmental Protection Agency) 2012b). Similar to the SVOCs, the metals induced no potential non-carcinogenic risk since both the HQ of each individual metal and the HI of all the metals were $<1.00$. This result is confirmed by previous studies demonstrating that metals in the Yangtze River source water pose negligible hazards to public health of local residents (Wu et al. 2010; Liu et al. 2011). It has also been indicated that metals in source water of Huaihe River (China) pose little threat to human health (Liu et al. 2012), but HQ (via ingestion) levels of metals in source water of the Khanpur Lake (Pakistan) are higher than 1.00 (Iqbal et al. 2012). This study showed that ingestion exposure led to higher non-carcinogenic risk than dermal contact, which is similar to the study from Iqbal et al. (2012). In the source water, the HI values of the metals via ingestion and dermal exposure were $3.00 \mathrm{E}-2$ and $8.59 \mathrm{E}-$ 4 , respectively. For the drinking water, the HI values were $3.46 \mathrm{E}-2$ (ingestion) and $1.86 \mathrm{E}-3$ (dermal). Among the metals, Al contributed most to the total non-carcinogenic risk via ingestion, followed by $\mathrm{Sr}, \mathrm{Fe}$ and $\mathrm{Ba}$, although concentrations of these elements were lower than most of the other elements. It is well known that $\mathrm{Al}, \mathrm{Ba}, \mathrm{Fe}$ and $\mathrm{Sr}$ in drinking water can cause metabolic/gastrointestinal disorders and cytotoxic and neurotoxic effects (WHO (World Health Organization) 2012). Interestingly, in the case of dermal exposure, Al contributed more than $80 \%$ to the total HI of the metals in both the source water and drinking water (Fig. 1b). This may result from the easy adsorption of the metallic element on skin to facilitate its absorption into human bodies (USEPA (US Environmental Protection Agency) 2012b, d). However, Liu et al. (2011) has indicated that $\mathrm{Pb}$ contributes most to $\mathrm{HI}$ of the metals in source water of Jiangsu Province (China), followed by $\mathrm{Cd}$ and $\mathrm{Cr}$. 
Fig. 1 Total non-carcinogenic hazard index (HI) of the detectable semi-volatile organic compounds (SVOCs) (a) and trace elements (b) in source water (SW) and drinking water (DW) (in black blot and line), and the contribution proportion of each detectable pollutant via ingestion (HQi) and dermal (HQd) exposure (in color rectangle). $B B P$ benzyl butyl phthalate, $H C C P$ hexachlorocyclopentadiene, $H C B$ hexachlorobenzene, $P C P$ pentachlorophenol, ISO isophorone, 2,4-DNT 2,4ditrotoluene, 2,6-DNT 2,6dinitrotoluene
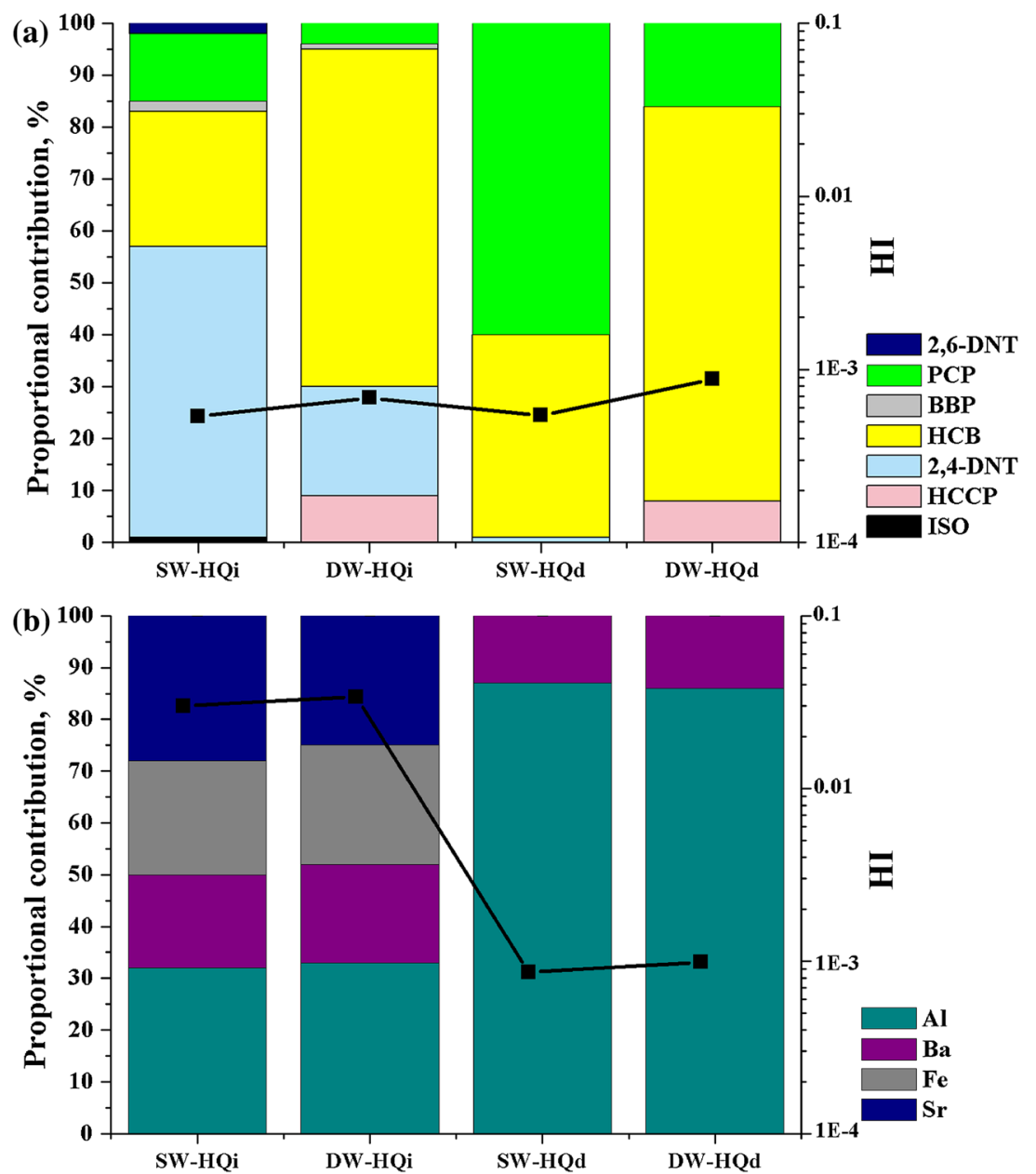

Carcinogenic risk of SVOCs and metallic elements

Under most regulatory programs, LCR value over $1.00 \mathrm{E}-6$ indicates potential carcinogenic risk (De Miguel et al. 2007). In this study, the metals in the source water and drinking water showed no carcinogenic risk (data not shown). Figure 2 shows the LCRs of the individual SVOCs and the integrated RIs of all the chemicals. Except for BaP, ingestion and dermal exposure to each SVOC in the source water and drinking water might induce no carcinogenic risk since the LCRs were $<1.00 \mathrm{E}-6$. Similarly, Li et al. (2012) have also indicated that OCCs, PAHs and PAEs in drinking water of several cities in Jiangsu Province pose no or little carcinogenic risk. However, our results showed that RI values of both the source water and drinking water exceeded $1.00 \mathrm{E}-6$ in the case of oral or dermal exposure, suggesting the joint carcinogenic risk induced by the various pollutants in the water.

Among the SVOCs in the source water, BaP seemed to have carcinogenic risk since the LCR value was $3.37 \mathrm{E}-6$ via ingestion exposure and $2.06 \mathrm{E}-5$ via dermal exposure, both higher than the safety level. For BaP in the drinking water, LCR via dermal exposure was $5.0 \times{ }^{-} 10^{6}$, but was $<8.17 \mathrm{E}-7$ via ingestion exposure. However, Shi et al.

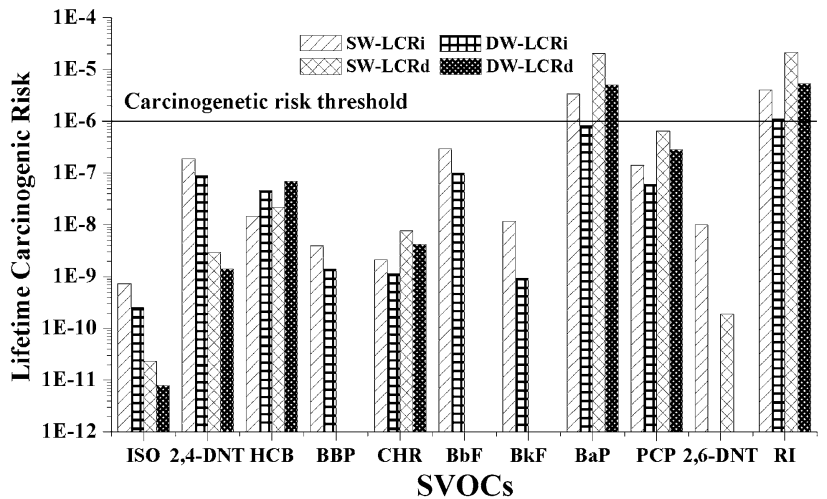

Fig. 2 Carcinogenic risk (RI) of the detectable semi-volatile organic compounds (SVOCs) in source water (SW) and drinking water (DW) via ingestion (LCRi) and dermal (LCRd) exposure. 2,4-DNT 2,4ditrotoluene, 2,6-DNT 2,6-dinitrotoluene, $B a P$ benzo(a)pyrene, $B b F$ benzo(b)fluoranthene, $B k F$ benzo(k)fluoranthene, $C H R$ chrysene, $B B P$ benzyl butyl phthalate, $H C B$ hexachlorobenzene, ISO isophorone, $P C P$ pentachlorophenol

(2011) revealed that dibenz[a,h]anthracene among the PAHs detected in Huaihe River contributed most to carcinogenic risk. It has been indicated that chronic exposure to $\mathrm{BaP}$ in drinking water can result in skin, lung, bladder, 
liver and stomach cancers in animals (Armstrong et al. 2004; Bosetti et al. 2005; Shimada and Fujii-Kuriyama 2004). Epidemiological studies have also confirmed that occupational exposure to $\mathrm{BaP}$ may increase the risk of skin, lung, bladder and gastrointestinal carcinogenesis in humans (Boffetta et al. 1997; Kogevinas et al. 2003), demonstrating that $\mathrm{BaP}$ in the drinking water of Yangtze River might pose potential carcinogenic health risk to the local consumers.

Effects of water treatment processes on reduction in health risk

The conventional drinking water treatment processes of coagulation/sedimentation, sand filtration and chlorine disinfection were found not effective in reducing potential noncarcinogenic health risk induced by SVOCs. The drinking water had higher non-carcinogenic risk than the source water, since total $\mathrm{HI}$ of the SVOCs via ingestion and dermal exposure was $1.08 \mathrm{E}-3$ for the source water and $1.56 \mathrm{E}-3$ for the drinking water (Fig. 1a). This might result from the increased level of OCCs in the drinking after chlorine disinfection (Table 1). This study indicated that the potential non-carcinogenic health risk induced by SVOCs in the drinking water was below safety level, but the increase in the concentrations of OCCs and other disinfection by-products induced by chlorination should receive more concern.

Overall, results showed that metallic elements caused higher non-carcinogenic risk than SVOCs, but the treatment processes were not effective in removal of the metals and reduction in the induced non-carcinogenic risk (Fig. 1b). Frequent use of polyaluminum flocculant in treatment processes might result in the high level of $\mathrm{Al}$ in the finished water (Dubey et al. 2009), so the non-carcinogenic risk induced by $\mathrm{Al}$ was high in drinking water, partially contributing the failure of the non-carcinogenic risk reduction.

The potential carcinogenic health risk of SVOCs in the source water was higher than the drinking water (Fig. 2), but the carcinogenic risk of drinking water still deserves great concern since its RI was higher than $1.00 \mathrm{E}-6$ (Fig. 2). Advanced processes have to be developed and applied in water treatment plants to ensure drinking water safety. So far, few studies have been conducted to investigate the health risk reduction in drinking water treatment plants. Our previous studies have shown that biofilters can effectively remove the SVOCs in drinking water, but the health risk induced by some PAEs and PAHs in the finished water cannot reach safety levels (Zhang et al. 2009, 2012).

\section{Conclusion}

This study assessed the carcinogenic and non-carcinogenic risks based on chemical detection of 22 SVOCs and 24 metallic elements in source water and drinking water at a full-scale water treatment plant of China. Various PAHs, OCCs, DNTs and metals are present in the water. Both the SVOCs and metals pose negligible non-carcinogenic risk, but the local consumers might suffer carcinogenic risk due to $\mathrm{BaP}$ exposure. The conventional water treatment processes have no obvious effects on the reduction in the induced carcinogenic and non-carcinogenic risks, and carcinogenic risk of the finished water should receive more concern. This study is expected to provide some useful baseline information for health risk assessment of drinking water. Advanced drinking water treatment processes should be developed and used to reduce public health risk in a more efficient manner.

Acknowledgments This study was financially supported by National Natural Science Foundation of China (No. 51290282 and 51278240).

\section{References}

Armstrong B, Hutchinson E, Unwin J, Fletcher T (2004) Lung cancer risk after exposure to polycyclic aromatic hydrocarbons: a review and meta-analysis. Environ Health Perspect 112:970-978

Babu SH, Kumar KS, Suvardhan K, Kiran K, Rekha D, Krishnaiah L, Janardhanam K, Chiranjeevi P (2007) Preconcentration technique for the determination of trace elements in natural water samples by ICP-AES. Environ Monit Assess 128(1-3):241-249

Boffetta P, Jourenkova N, Gustavsson P (1997) Cancer risk from occupational and environmental exposure to polycyclic aromatic hydrocarbons. Cancer Cause Control 8:444-472

Bosetti C, Boffetta P, La Vecchia C (2005) Occupational exposures to polycyclic aromatic hydrocarbons, and respiratory and urinary tract cancers: a quantitative review to 2005. Ann Oncol 18:431-446

Chen SC, Liao CM (2006) Health risk assessment on human exposed to environmental polycyclic aromatic hydrocarbons pollution sources. Sci Total Environ 366:112-123

Chen Y, Zhang XX, Wu B, Liu B, Xiao L, Li AM, Cheng SP (2012) Semivolatile organic compounds removal and health risk reduction in drinking water treatment biofilters applying different backwashing strategies. Int J Environ Sci Technol 9:661-670

Corsini E, Liesivuori J, Vergieva T, Loveren HV, Colosio C (2008) Effects of pesticide exposure on the human immune system. Hum Exp Toxicol 27:671-680

Dąbrowski A, Podkościelny P, Hubicki Z, Barczak M (2005) Adsorption of phenolic compounds by activated carbon-a critical review. Chemosphere 58(8):1049-1070

De Miguel E, Iribarren I, Chacon E, Ordonez A, Charlesworth S (2007) Risk-based evaluation of the exposure of children to trace elements in playgrounds in Madrid (Spain). Chemosphere 66:505-513

Dubey SP, Gopal K, Bersillon JL (2009) Utility of adsorbents in the purification of drinking water: a review of characterization, efficiency and safety evaluation of various adsorbents. J Environ Biol 30(3):327-332

Florentina A, Hautemanièrea A, Hartemanna P (2011) Health effects of disinfection by-products in chlorinated swimming pools. Int $\mathbf{J}$ Hyg Environ Health 214:461-469

Grimmett PE, Munch JW (2013) Development of EPA Method 525.3 for the analysis of semivolatiles in drinking water. Anal Methods 5:151-163 
Han F, Chen J, Jiang Z, Chen L, Ji W (2013) Volatile and semivolatile organic compounds in the lower Yangtze River and surface waters of three Chinese provinces. Pol J Environ Stud 22(3):683-690

Iqbal J, Tirmizi SA, Shah MH (2012) Non-carcinogenic health risk assessment and source apportionment of selected metals in source freshwater Khanpur Lake, Pakistan. Bull Environ Contam Toxicol 88:177-181

Kogevinas M, Mannetje A, Cordier S, Ranft U, Gonzalez CA, Vineis $\mathrm{P}$ (2003) Occupation and bladder cancer among men in Western Europe. Cancer Cause Control 14:907-914

Król S, Zabiegała B, Namieśnik J (2011) Monitoring and analytics of semivolatile organic compounds (SVOCs) in indoor air. Anal Biochem Chem 400(6):1751-1769

Li GC, Xia XH, Yang ZF, Wang R, Voulvoulis N (2006) Distribution and sources of polycyclic aromatic hydrocarbons in the middle and lower reaches of the Yellow River, China. Environ Pollut 144(3):985-993

Li B, Qu CS, Bi J (2012) Identification of trace organic pollutants in drinking water and the associated human health risks in Jiangsu Province, China. Bull Environ Contam Toxicol 88:880-884

Liu N, Ni TH, Xia J, Dai MZ, He CY, Lu GF (2011) Noncarcinogenic risks induced by metals in drinking source water of Jiangsu Province, China. Environ Monit Assess 177:449-456

Liu N, Zhu QY, Qian X, Yang L, Dai MZ, Jiang XQ, Li N, Sun L, Liu ZC, Lu GF (2012) Non-carcinogenic risks induced by heavy metals in water at source from Huaihe River, Jiangsu Province, China. Pol J Environ Stud 21:967-972

McLean D, Eng A, Dryson E, Walls C, Harding E, Wong KC, Cheng S, Mannetje A, Ellison-Loschmann L, Slater T, Shoemack P, Pearce N (2009) Morbidity in former sawmill workers exposed to pentachlorophenol (PCP): a cross-sectional study in New Zealand. Am J Ind Med 52:271-281

MHPRC (Ministry of Health of the People's Republic of China) (2012) Annual report of China health statistics. http://www.moh. gov.cn/zwgkzt/ptjnj/200809/37759.shtml. Accessed on 24 Sep 2012

Muller B, Berg M, Yao ZP, Zhang XF, Wang D, Pfluger A (2008) How polluted is the Yangtze River? Water quality downstream from the Three Gorges Dam. Sci Total Environ 402:232-247

Neal C, Neal M, Hill L, Wickham H (2006a) The water quality of the River Thame in the Thames basin of south/south-eastern England. Sci Total Environ 360:254-271

Neal C, Neal M, Hill L, Wickham H (2006b) The water quality of the River Thame in the Thames basin of south/south-eastern England. Sci Total Environ 360:254-271

Noubactep C (2010) Metallic iron for safe drinking water worldwide. Chem Eng J 165(2):740-749

Oliver BG, Nlcol KD (1982) Chlorobenzenes in sediments, water, and selected fish from Lakes Superior, Huron, Erie, and Ontario. Environ Sci Technol 16(8):532-536

Orton F, Lutz I, Kloas W, Routledge EJ (2009) Endocrine disrupting effects of herbicides and pentachlorophenol: in vitro and in vivo evidence. Environ Sci Technol 43:2144-2150

Qin F, Zhao YY, Zhao YL, Boyd JM, Zhou WJ, Li XF (2010) A toxic disinfection by-product, 2,6-dichloro-1,4-benzoquinone, identified in drinking water. Angew Chem Int Edit 49:790-792

Reed L, Buchner V, Tchounwou PB (2007) Environmental toxicology and health effects associated with hexachlorobenzene exposure. Rev Environ Health 22:213-243

Shi W, Zhang FX, Zhang XW, Su GY, Wei S, Liu HL, Cheng SP, Yu HX (2011) Identification of trace organic pollutants in freshwater sources in Eastern China and estimation of their associated human health risks. Ecotoxicology 20:1099-1106

Shi P, Jia S, Zhang X-X, Zhang T, Cheng S, Li A (2013) Metagenomic insights into chlorination effects on microbial antibiotic resistance in drinking water. Water Res 47(1):111-120

Shimada T, Fujii-Kuriyama Y (2004) Metabolic activation of polycyclic aromatic hydrocarbons to carcinogens by cytochromes P450 1A1 and 1B1. Cancer Sci 95:1-6

Sun C, Dong Y, Xu S, Yao S, Dai J, Han S, Wang L (2002) Trace analysis of dissolved polychlorinated organic compounds in the water of the Yangtse River (Nanjing, China). Environ Pollut 117(1):9-14

USEPA (US Environmental Protection Agency) (2012a) Exposure Factors Handbook. National Center for Environmental Assessment Office of Research and Development. http:www.cfpub.epa. gov/ncea/cfm/recordisplay.cfm?deid $=22463$. Accessed on 24 Sep 2012

USEPA (US Environmental Protection Agency) (2012b) Residential Tap Water Supporting Table. http: www.epa-prgs.ornl.gov/ chemicals/index.shtml. Accessed on 24 Sep 2012

USEPA (US Environmental Protection Agency) (2012c) Risk Assessment Guidance for Superfund Volume I: Human Health Evaluation Manual (Part A). http:www.epa.gov/raf/publications/ pdfs/GUIDELINES_EXPOSURE_ASSESSMENT.PDF. Accessed on 24 Sep 2012

USEPA (US Environmental Protection Agency) (2012d) Risk Assessment Guidance for Superfund Volume I: Human Health Evaluation Manual (Part E, supplemental guidance for dermal risk assessment). http:www.epa.gov/superfund/programs/risk/ ragse/index.htm. Accessed on 24 Sep 2012

WHO (World Health Organization) (2012) Guidelines for DrinkingWater Quality: Recommendations Incorporating $1^{\text {st }}$ and $2^{\text {nd }}$ Addenda, vol. $1,3^{\text {rd }}$ ed. http:http://www.who.int/water sanitation_health/dwq/gdwq3rev/en/. Accessed on 24 Sep 2012

Wu B, Zhang XX, Zhang XL, Yasun ASJ, Zhang Y, Zhao DY, Ford T, Cheng SP (2009a) Semi-volatile organic compounds and trace elements in the Yangtze River source of drinking water. Ecotoxicology 18:707-714

Wu B, Zhao DY, Zhang Y, Zhang XX, Cheng SP (2009b) Multivariate statistical study of organic pollutants in Nanjing reach of Yangtze River. J Hazard Mater 169(1-3):1093-1098

Wu B, Zhang Y, Zhang XX, Cheng SP (2010) Health risk from exposure of organic pollutants through drinking water consumption in Nanjing, China. Bull Environ Contam Toxicol 84:46-50

Wu B, Zhang R, Cheng SP, Ford T, Li AM, Zhang XX (2011a) Risk assessment of polycyclic aromatic hydrocarbons in aquatic ecosystems. Ecotoxicology 20:1124-1130

Wu B, Zhang Y, Zhang XX, Cheng SP (2011b) Health risk assessment of polycyclic aromatic hydrocarbons in the source water and drinking water of China: quantitative analysis based on published monitoring data. Sci Total Environ 410-411: $112-118$

Xie SH, Liu AL, Chen YY, Zhang L, Zhang HJ, Jin BX, Lu WH, Li XY, Lu WQ (2010) DNA damage and oxidative stress in human liver cell 1-02 caused by surface water extracts during drinking water treatment in a waterworks in China. Environ Mol Mutagen 51:229-235

Xu SY, Gao XJ, Liu M, Chen ZL (2001) China's Yangtze estuary: II. Phosphorus and polycyclic aromatic hydrocarbons in tidal flat sediments. Geomorphology 41:207-217

Zhang J (1995) Geochemistry of trace metals from Chinese river/ estuary systems: an overview. Estuar Coast Shelf Sci 41:631-658 
Zhang ZL, Hong HS, Zhou JL, Yu G (2004) Phase association of polycyclic aromatic hydrocarbons in the Minjiang River estuary, China. Sci Total Environ 323(1-3):71-86

Zhang Y, Zhang XX, Wu B, Zhao DY, Li M, Cui YB, Ford T, Cheng SP (2009) Degradation of benzo(a)pyrene in Yangtze River source water with functional strains. Ecotoxicology 18:742-747

Zhang RF, Wang WL, Shi XR, Yu XZ, Li M, Xiao L, Cui YB (2011) Health risk of semi-volatile organic pollutants in Wujin River inflow into Taihu Lake. Ecotoxicology 20:1083-1089
Zhao YL, Anichina J, Lu XF, Bull RJ, Krasner SW, Hrudey SE, Li XF (2012) Occurrence and formation of chloro- and bromobenzoquinones during drinking water disinfection. Water Res 46:4351-4360

Zhu LZ, Chen YY, Zhou RB (2008) Distribution of polycyclic aromatic hydrocarbons in water, sediment and soil in drinking water resource of Zhejiang Province, China. J Hazard Mater 150(2):308-316 